$12-29-2017$

\title{
Community-based descriptive Orthography of Surigaonon language
}

Mariyel Hiyas Liwanag

University of the Philippines Los Baños, mcliwanag2@up.edu.ph

Follow this and additional works at: https://scholarhub.ui.ac.id/ajce

Part of the Social and Behavioral Sciences Commons

\section{Recommended Citation}

Liwanag, Mariyel Hiyas (2017). Community-based descriptive Orthography of Surigaonon language. ASEAN Journal of Community Engagement, 1(2).

Available at: https://doi.org/10.7454/ajce.v1i2.91

Creative Commons License

(c) (i) ()

This work is licensed under a Creative Commons Attribution-Share Alike 4.0 License.

This Research Article is brought to you for free and open access by the Universitas Indonesia at ASEAN Journal of Community Engagement. It has been accepted for inclusion in ASEAN Journal of Community Engagement. 


\title{
Community-based Descriptive Orthography of Surigaonon Language
}

\author{
Mariyel Hiyas Liwanaga* \\ aUniversity of the Philippines Los Baños
}

Received: October 27th 2017 || Revised: November $12^{\text {th }}$ \& November 26 $6^{\text {th }}, 2017$ || Accepted: November $29^{\text {th }}, 2017$

\begin{abstract}
With the implementation of Mother Tongue-based Multilingual Education (MTBMLE) framework, there is a dire need to create community-based standardization of orthography for native languages in the Philippines, and this includes the Surigaonon language as only few languages in the Philippines have educational materials written for teaching and learning the mother tongue. Moreover, the development of such materials rarely involves community participation. This research aims to provide preliminary points of discussion for language policymakers and create an alternative in developing materials through community engagement. Using the Community-based Approach to Orthography Development by Catherine Easton in 2003, this study asked seventy (70) Surigaonon speakers from different parts of the province to spell out 78 items of Surigaonon words, phrases, and sentences. From this corpus, the researcher analyzed the forms of several initially observed orthographic issues. Out of 18 consonants and 3 vowels that exist in the language, five critical orthographic issues were identified. These key issues are significant in the continuous development of Surigaonon orthography. The first two issues that arose from this study are the inconsistent forms for the vowel sounds [I] and [u]. Though the written form $i$ is mostly used for the [I] sound, the $[\mathrm{u}]$ sound remains unpredictable as it is either spelled out $u$ or $o$. The same case of unpredictability occurs with the affricates [dz] and [t]]. The former is spelled out as either $j, d j, d z$, or $d s$ while the latter is spelled out as ts or ch. Lastly, the use of dash is erratic as a representation for a glottal stop between vowels. This community engagement approach provides an alternative to the traditional elicitation of data for language education materials. This methodology gives the community the access to participate in language planning.
\end{abstract}

Keywords: community engagement; orthography; Surigaonon; language policy and planning; language education material

\section{Introduction}

The Mother Tongue-based Multilingual Education (MTBMLE) framework of the Philippine Department of Education (DepEd) under Department Order 16 of 2012 aims to include the mother tongue as a subject area and to implement the use of mother tongue as a language of instruction and discussion inside the classrooms for other subject areas from pre-school to Grade 3. Initially, the program was offered in a limited number of languages despite the Philippine ethnolinguistic groups having more than 180 languages. As of 2016, DepEd teaches different subject areas in Grades 1 to 3 in 19 languages: Akianon, Bahasa Sug, Bikol, Chavacano, Hiligaynon, Ibanag, Iloko, Ivatan, Kapampangan, Kinaray-a, Maguindanaoan, Maranao, Pangasinan, Sambal, Surigaonon, Sinugbuanong Binisaya, Tagalog, Waray, and Yakan (Republic of the Philippines Department of Education, 2016).

With the implementation of the framework, development of language materials is necessary, especially since the mother tongue is taught as a subject area. Included in these materials is the standardization of language. Teresita Fortunato and Maria Stella Valdez (1995:84) define standardization as the creation of rules for uniformity or basis for judgment and the use of these rules in language use. The Philippine government for the longest time has been attempting to provide language standardization for the national language and the languages in the Philippines. The standardization of language, specifically orthography, is the process of providing written symbols as representations

*Correspondence Author: mcliwanag2@up.edu.ph 
of sounds in oral communication of a language as defined by Fortunato and Valdez (1995).

The national language Filipino has always been a subject of interest for standardized orthography as evident in the history of language planning and policies. Fortunato and Valdez (1995:84) narrate in their book the history of standardizing Filipino orthography starting from the pre-Hispanic period. They recount that long before the arrival of Spaniards in the Philippines, Filipinos already had their writing system called baybáyin and most of the Filipinos knew how to read and write as their laws and literature were written on tree barks, leaves, or bamboos. The baybáyin writing system has variants like the Palawan scripts, Kulitan, Surat Mangyan, and Surat Tagalog (de los Santos, 2015) and all are in the forms of syllabary writing. From the syllabary form of writing, the Spaniards introduced the romanization of the Philippine writing system and came up with 29 alphabetic letters including the $\tilde{n}$; eventually, these 29-alphabetic letters were trimmed down to 20 during the Commonwealth period under the Americans (Fortunato \& Valdez, 1995:89). These 20 alphabetic letters became 31 in 1976 with the addition of 11 more letters under the assumption of enriching the orthography of Filipino. Eventually, according to Galileo S. Zafra (2005:254), the letters ll, rr, and ch were removed in the revised 1987 The Alphabets and Orthographic Guide for Filipino [my translation of 'Alpabeto at Patnubay sa Ispeling ng Wikang Filipino'] under Institute of Philippine Languages. The 2001 revision of 1987 The Alphabets and Orthographic Guide for Filipino still acknowledges the 28 alphabets for writing Filipino but installed new rules in using the letters c, f, j, ñ, q, v, x, and z.

Despite the 1987 Constitution's mandate for Filipinos to recognize the languages in the Philippines, the emergence of standardization for other Philippine languages had only intensified when MTBMLE was implemented under the K-12 framework of the Department of Education (DepEd). The Commission of Filipino Language or Komisyon sa Wikang Filipino (2016a, 2016b, 2016c, 2016d, 2016e), the language agency of the government, has published orthography for different languages: Itawit, Kalanguya, Malaweg, Ibaloy, Pangasinan.

As mentioned by Ibon Foundation, Inc. (2004), one of the myths in the field of research is that people believe that this endeavor is reserved for intellectuals, the standardization of orthography has also been the center of political issues for a considerable period. Rifts between intellectuals of varying disciplines, language organizations and groups emerged due to different standards of spelling. However, the issue of standardization has always been attached to the language intellectuals, even though the language is significant to the community at large. As argued by Tauli (in Victor, 2005), language is important to a community as it is used for communication.

This preliminary study aims to create a Surigaonon orthography based on the community engagement as a complement to all existing studies for the language. With 88,129 households as speakers, Surigaonon, according to the 2002 Census (in Dumanig, 2015), is the fourth most spoken language in Region XIII (CARAGA) composed of Surigao Province (del Norte and del Sur), Agusan Province (del Norte and del Sur), and Dinagat Islands. Surigaonon is alternatively called Jaun-jaun, Sinurigao, Waya-waya and has a population of 400,000 speakers as of 2009 (Simons \& Fennig, 2017).

Few research has been conducted regarding Surigaonon and standardization of the language has been attempted by DepEd and other individuals. N. O. Tiukinhoy 's unpublished master's thesis entitled Isang pahambing na pagsusuri ng mga pandiwang di-karaniwan sa wikaing Surigaonon at sa wikang Filipino sa larangan ng morpolohiya ayon sa tatlong aspekto ng mga pandiwa [A comparative analysis of irregular verbs in 
Surigaonon and Filipino language in the field of morphology according to the three aspects of verbs (translation mine)] focused more on the morphological processes involved in Surigaonon irregular verbs. This is followed by Dumanig and Jubilado's (2006) morphophonemic study on the effects of word-formation to sounds. These studies are theoretical and focus on word formation and its effect on sounds and other morphemes. However, these studies remain significant additions to the body of knowledge for Surigaonon.

Aside from theoretical studies, educational materials emerged for Surigaonon. Language materials such as dictionaries were also produced during the 2000's. Fredesuendo Ong's (2004) Surigaonon Words and Expressions is first among the locally published dictionary. This bilingual dictionary contains terms and expressions in Surigaonon and their English counterparts; each word was written using the alphabetic system of Spanish. Therefore, the book follows the principle of using Spanish alphabets in spelling. For example, the sound /kamo/ or 'you' are spelled out as camo (Ong, 2004). Similarly, Samson Deliupa (2012) produced his English-Surigaonon Surigaonon-English Dictionary. His dictionary contains more than 8,000 Surigaonon terms and more than 2,000 English words with their Surigaonon counterparts (Deliupa, 2012). The same sound /kamo/ is written in his dictionary as kamo (Deliupa, 2012).

Dictionaries are not the only ones developed through the 2010's as descriptive linguistic studies have emerged as well. Francis Tom Paredes (2014) published Sinurigao: Pormada, Plastada, Tunada, Pasabot with the aim to help teachers in teaching or using Surigaonon as his booklet serves as a teaching aid across all educational levels. His book contains a sound inventory of the language, parts of speech, punctuations, and morphological and phrasal syntax. Additionally, I was also able to develop A Grammar Sketch of Surigaonon that focuses on syntactical structures of basic sentences in Surigaonon as a partial requirement for my master's degree (Liwanag, 2015). However, the grammar sketch that I have created focused mainly on syntax and only provided snippets of Surigaonon phonological and morphological aspects. This research gap was complemented by Francis P. Dumanig in 2015. In the very same year of the approval of my grammar sketch, Dumanig (2015) also released his study Descriptive Analysis of Surigaonon Language. He also noted the sound inventory present and described the morphophonemic changes. His study noted 17 consonants /b/, /d/, /p/, /g/, /k/, /t/, /j/, /m/, /n/, /y/, /r/, /l/, /s/, /w/, /y/, /h/, and / / / and 3 vowels /i/, /a/, and /u/ for the language. He also recognized that in spite of having three vowels noted in spoken discourse, speakers use five vowel forms in their written discourse. This is part of the issue recognized in the orthography of Surigaonon.

Additionally, DepEd tried to standardize Surigaonon language, especially the standards of orthography, because of MTBMLE. Their working material called Magbasa na Kita explained the old way of writing using Spanish alphabets, like Ong's dictionary. In Magbasa na Kita, often used letters were determined through word count of a 4,000word story and served as the base of the working orthography (Givertz, et al., 2013). Given the limited number of linguistic and language education outputs, the establishment of standardized Surigaonon has yet to be achieved and is strongly needed especially with the ongoing implementation of MTBMLE. The call for authentic and democratic standardization of Surigaonon language strongly requires community engagement in the creation. Thus, this study aims to provide options from democratic consultations to have a basis for the orthography developers in improving existing orthography material in MTBMLE as it is necessary for Surigaonon language to remain a mother tongue in CARAGA. Aside from the lack of mentioning or including of grassroots engagement, the 
module created by the Regional DepEd also remains preliminary, only introducing the alphabetic letters of Surigaonon and excluding the grammatical rules. Though the number of participants and the demographics can be considered limited, this study aims to have a preliminary basis for an orthography development and to broaden the democratic engagement by reaching out to other sectors of the community - including the farmers and fisher folks, the professionals, the children, and other members of Surigao del Norte.

In fact, several types of research from overseas have adapted orthography development through community engagement. Kirk R. Person (2001) has published a paper on a community-based approach on orthography development of Bisu in Chiang Rai, Thailand using the maximum criteria developed by Susan Malone and Dennis Malone: motivation for the leaners and acceptance of the society, representation, ease of learning, transfer, and reproduction. Using Malone and Malone's approach, standardization of the vowels, consonants, tones, and external influences such as loans, breaks, and variations were developed for Bisu language (Person, 2001). Catherine Easton (2003) conducted a community-based approach for alphabetic design under orthography development for Papua New Guinea. Her study's framework and methodological design were used for this study. Brendon Yoder (2017), using Catherine Easton's approach in the Alphabet Design Workshop, helped develop an orthography for Abawiri. Yoder (2017) asked community leaders to write spontaneously using their basic knowledge of Indonesian orthography, and their outputs were then compared. This study uses the foundation approach of Easton (2003) and Yoder (2017).

\section{Theoretical background}

This research used the Community-based Approach to Orthography Development by Catherine Easton in 2003. She used this approach to orthography development in Papua New Guinea during the 1990s. This approach to orthography is applied so that the community will have a sense of involvement in creating their orthography.

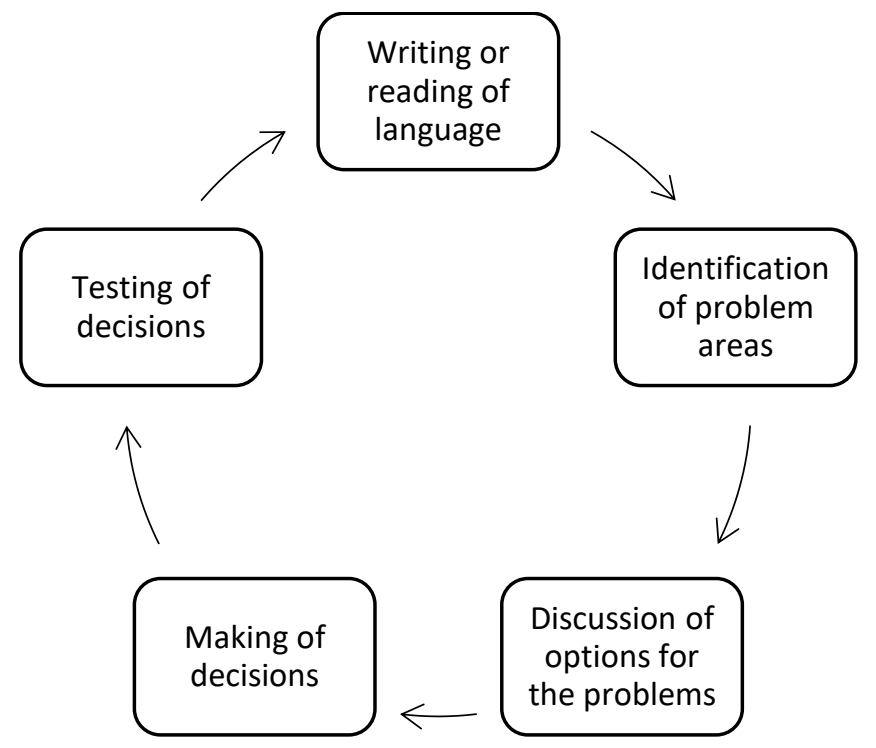

Fg. 1 Easton's (2003) Orthography Development Approach

This approach by Easton (2003) is cyclical, following the process of 1) writing or reading language, 2) identifying the problem areas, 3) discussing options for the problems, 4) making decisions, and (5) testing the decisions. After the fifth part of the 
process, the developers return to the first part of the process. The first part (writing or reading language) involves the production of wordlists, writing and reading stories, and playing word games. This part is followed by the second part, isolating problem areas in which inconsistencies in spelling and difficulty in reading and writing are determined. These inconsistencies and difficulty are then provided with options or choices as consulted. Lastly, decisions on orthography are decided either by the participants or language community members. These decisions are eventually tested through community feedback and development of materials for writing and reading. These materials will then be used for identification of problem areas, and the cycle of orthography development continues until such time that the language community has its strong development of orthography.

Changes in attitude and methodology in the approach of orthography development were observed in this process (Easton, 2003). The first change comes with the attitude of the researchers. Easton (2003) explained that the researcher functions only as a facilitator and accepts the whole data with their limitations and imperfections. As noted in a Summer Institute of Linguistics (SIL) report (in Easton, 2003), "the ownership of the orthography... is in the hands of the speakers of a language. They must make the decisions regarding how the orthography should look how to spell the language." The second change occurs in the methodology. Traditionally, researchers develop or use generic, random wordlist to generate data for analyses. In the Community-based Approach to Orthography Development by Catherine Easton, wordlists are developed under the direction of natives.

In this approach, the constituents are involved in the decisions of Surigaonon standardization. This study provides the first three parts of the process for the language policymakers to have a basis for making decisions on orthography.

\section{Methods}

In an initial linguistic research for the development of the language's grammar sketch, Variations of spelling for some words were noticed. With the initially observed variations as a basis, a list of 78 words and sentences was developed together with Surigaonon natives. These items were predetermined so that varieties in written form are to be noted. The entries for the list contain vowels, consonants specifically affricate, and glottal stop as these sounds are considered debatable among native speakers.

The list was counterchecked by Surigaonon natives before administration. Seventy college students from different areas of Surigao del Norte were interviewed and asked to participate. The process of gathering the written variations for the predetermined words and sentences started with the researcher providing an explanation about the study. The participants were also reminded at the beginning and during the data collection to spell out the spoken words or sentences according to how they write these in their everyday lives. The words or sentences were articulated by a Surigaonon native speaker while a participant spelled out the word based on what s/he had heard.

All collected outputs from participants were then collated, and the variations of orthographic form for each entry in the list were noted. From the collected data, the researcher determined and presented all written variations for specific entries below.

\section{Results and Discussion}

On July 6, 2015, this study consulted 70 Surigaonon speakers from different parts of Surigao del Norte and Dinagat Island. Even though the latter was already a separate 
province under the Republic Act 9355 in 2006, the speakers from the area still refer to their language as Surigaonon.

Their initial reactions upon hearing the words "spelling of Surigaonon" were a mixture of excitement and fear. Some fear that they might get wrong answers, to which the researcher immediately explained that their answers would not be judged and tagged as right or wrong so they could spell the words as they normally did. This gave them the feeling of assurance in writing. This approach elicited 8,239 entries from 70 native speakers. All speakers agreed to take part in further interviews and studies, depending on their schedules as most of them attend classes or have part-time jobs.

The data from my previous fieldwork complemented the current data from the participants. In my 2014 fieldwork in Surigao City as part of my master's thesis, $A$ Grammar Sketch of Surigaonon, 19 consonants and semi-vowels for Surigaonon have been documented. The following Surigaonon consonants are represented by their expected orthographic form as can be observed from Table 1 below. The same rule of Commission of Filipino Language that the form should follow the sound (Almario, 2013) is followed by these consonants with exception to the affricates as these will be discussed in-depth later on.

Table 1. Examples with definitions of Surigaonon consonants

[b] buyak (flower), abot (to pass), huy-abb (to yawn)

[k] koman (now), bakak (to lie)

[d] duwa (to play), kada (every), edad (age)

[g] gantang (measurement for rice), bugas (rice), bukag (container), bungkag

(to separate)

[h] hampay (to play), bahandi (wealth)

[l] láong (to say), palihog (please), tinabal (dried fish)

[m] mingaw (sadness due to longing), hamok (plenty), hilam (mosquito)

[n] nawong (face), hupnig (to put in order), tanan (all)

[y] ngaj-an (later), nganga (betelnut), nawong (face)

[p] panuhot (illness similar to arthritis caused by cold weather), sipa (to

kick), ihap (to count)

[r] rekado (ingredients), parehas (same), tukar (to play musical instrument)

[s] s sulti (to talk), pastilan (what a pity), pahukas (dowry)

[t] tahi (to sew), hatod (to accompany), buhut (tobacco)

[w] waldas (to spend extravagantly), pawa (to clear a space), tuwaw (to cry)

[j] yaot (ugly), huyup (to blow), bayay (house), mananambay (quack doctor)

This result complements the documentation done by Dumanig (2015). Dumanig (2015) mentioned that Surigaonon language has three vowels [a, i, u] though the English alphabetic vowel forms [a, e, i, o, u] are used in spelling variably. This is particularly true based on the collated data from the participants. The use of the form $a$ is consistently used for all [a] sounds, regardless of the position and the environment. This is observed from the following Surigaonon words bakak (liar), bayay (house), abtik (fast), tanan (all), mananambay (traditional healer), and sipa (kick).

However, the orthographic variations $i$ and $e$ are observed for the [I] sound. For example, the sound [Idad] (age) was spelled out by most of the participants as edad of its Spanish origin. Though edad is the most common spelling, another form is also used by some: idad. Another Spanish loan with different spelling in Surigaonon is [rikado] (ingredient). The Surigaonons follow the spelling rekado even though the variants recado and rikado are also seen. This shows that not all Spanish loans are spelled out as is in their 
original language. Another example of these variations of [I] sound is the spelling of the word [hilam] with the most used form hilam (mosquito) and another form helam. This is also the case for the following examples:

1. [Ihap] (to come):

2. [tahI] (to sew):

ihap, ehap

3. [pastilan] (expression for loss opportunity or empathy):

tahi, tahe

4. [limpyo] (to clean):

pastilan, pastelan

5. [taghigugma] (to be loved):

limpyo, lempyo

taghigugma, tag higugma, tag-

higugma, taghegugma

For these five examples above, the [I] sound is often spelled out with the $i$ form and rarely with the $e$ form. This notion is similar with the idea in the Orthography Guide for Filipino Language in 2013 as released by Commission of Filipino Language that the form should be based on how sound is articulated (Almario, 2013). Though variations exist for the [I] sound in the examples above, some words seem to have a fixed form like the words sulti (to speak), sija (third person singular nominative), and nija (third person singular accusative). The variations of $i$ and $e$ remain a debate among native speakers. Similarly, orthographic variations $o$ and $u$ are observed for [u] sound as observed in the following examples:

6. [buyak] (flower):

7. [abut] (to reach):

8. [la?ung] (to say):

9. [kuman] (now):

10. [bungkag] (to dig):

11. [nawuy] (face):

12. [wayun] (face):

13. [panuhut] (coldness in the body):

14. [pahukas] (dowry): buyak, boyak, buak

abot, abut

laong, laung, la-ong

kuman, koman, ku-man

bungkag, bongkag

nawong, nawung

wayong, wayung

panuhot, panuhut

pahukas

However, the concept of Orthography Guide for the Filipino Language in 2013 as released by Commission of Filipino Language that sound should be the basis for the form (Almario, 2013) is not consistently observed across examples of [u] sounds. Unlike the [I] sound with the often used $i$ form, the $[\mathrm{u}]$ sound does not have a consistently used form. The first example [buyak] (flower), follows the Commission's concept of sound as basis for form. The same goes for examples (9) and (10). Respectively, the words [kuman] (now) and [bungkag] (to dig) follow the general rule by the Commission. However, some words do not subscribe to the same concept as seen in examples (7), (8), (11), and (12). To elaborate, two morphological varieties [nawuy] and[wayun] for face are spelled out with $o$ form instead of $u$.

Clearly, the rules for writing the Surigaonon vowels are blurred. The vowel [a] is consistently written as $a$ while the [i] sound has two distinct forms $i$ or $e$. However, it is notable that the more widely used form is $i$. Unlike the consistent use of $a$ for [a] and the more widely used $i$ for [i], the [u] sound has inconsistent forms $o$ and $u$. This is a point of discussion for the language policymakers as the third part of the orthography development process. 
This inconsistency of written forms is not only observable in vowels but also in specific consonant sounds in Surigaonon, especially in affricates - the [dz] and [t $f]$. The [dz] sound has a consistent orthographic form of $j$ as seen in the first three examples below. The word [gadzud] in example (15) has a consistent use of $j$ form for the [dz] sound. Similarly, this is also the circumstance for [sidza] and [dzawdzaw] since the [dz] sound for both are represented by the $j$ form. However, the situation differs for examples (18) and (19).
15. [gadzud] (really):
16. [sidza] (third person singular):
17. [dzawdzaw] (to utter):
18. [dzagan] (to run):
19. [yadzian] (now):

\author{
gajud \\ sija \\ jaw-jaw, jaw jaw, jawjaw \\ jagan, djagan, dyagan \\ ngadj-an, ngaj-an, ngads-an, \\ ngadz-an
}

In (18) and (19), different forms represent the [d3] sound. For example (18), the sound has three possible forms: $j, d j$, and $d y$. The majorly used one is the $j$ form while the second and the third are few yet realistically used by other people. This is slightly different from example (19). In (19), the word [yadz?an] is typically spelled out as ngadj-an, ngaj-an, ngads-an, or ngadz-an. Most participants used the $d j$ form for it as opposed to the use of $j$ for [dzagan]. Therefore, the need to settle how the [dz] sound is to be spelled out should be decided by the language policymakers.

Another affricate that needs to be discussed in depth by language policymakers is the $[\mathrm{t}]$ ] sound. Similar to [dz], the [t $\mathrm{t}]$ sound has different forms in writing. The word [t $\mathrm{tapa}]$ (badge) is spelled out either as chapa or tsapa. Most of the participants spelled out the word as chapa though some spell it out as tsapa. This orthographic outcome for the [ $\mathrm{t}]$ ] sound, though, is different from the[t $\mathrm{f}]$ of the word [itfa] (throw). The latter word is spelled out unanimously by all participants as itsa. This time, the [t $\mathrm{t}]$ sound is represented by the form ts instead of $c h$. Initially, the notable aspect of these two distinguished forms is that the ch is used for a Spanish loan word while the ts form is used for an indigent word. However, upon taking into consideration another Spanish loanword [t famba] (fluke), one can deduct that the initial note on the orthographic form of [ $\mathrm{t}]]$ is considered null as majority of the participants spelled out the second loan word [t $\mathrm{t}$ amba] as tsamba while only several of them used the variant chamba. Language policymakers and researchers should gather more data to further analyze the orthographic form for these two affricates [dz] and [t $]$.

Lastly, the inconsistency in the use of dash in Surigaonon orthography is observed in the corpus of the study. The use of dash in Surigaonon often occurs between two vowels or sometimes a consonant and a vowel. Examples for these circumstances are provided below. First and oftentimes, the use of dash is observed as an orthographic counterpart for the glottal stop [?] between two vowels as observed from example (8) repeated here as (20):

$$
\text { 20. [la?ung] (to say): }
$$

laong, laung, la-ong

As observed from the example above, the third variant la-ong was spelled out by some participants to denote a glottal stop between the [a] and the [u] sound while majority left out the dash and spelled the word continuously. However, the use of dash between two vowels is inconsistent as seen in the word [tagsinbu?bu?an] below. 


\section{1. [tagsinbu?bu?an]}

(accusative form of to water):

Most of the participants spelled out the first variant and only few provided the format of tagsinbubu-an. However, for the next example, the use of dash is evident and this is in the case of a glottal stop between an approximant consonant sound and a vowel. In example (22), most of the participants spelled out [hujiab] (to blow) with a dash between the approximant sound $[j]$ and the vowel sound $[a]$ and only one participant spelled out the word without a dash.

22. [huj?ab] (to blow):

huy-ab, hoy-ab, huyab

23. [tag?itfa] (accusative form of to throw): tag-itsa, tag itsa

The participants' use of dash is also noted between a consonant and a vowel as seen in (23) above. Majority of the participants used dash and only two of them used the second form of having a space between the verb [?itfa] and the aspect [tag]. An additional example of consistency in the use of a dash between a consonant and a vowel is the form used by all participant unanimously, which is the word [sud?an] (viand). All participants of the study spelled out this word as sud-an.

This use of dash is also a consistent part of the formula in writing for repeated sounds as seen in examples (24) and (25) below.

24. [dzawdzaw] (to mutter incomprehensibly):

jaw-jaw

25. [tagsinpintıkpintık] (accusative form of to flick):

tagsinpintik-pintik

Though the use of dash is consistent for repeated sounds, it remains inconsistent for its other appearances especially as a form of a glottal stop between vowels or a consonant and a vowel.

These findings are bases that language policymakers can use in order to make decisions on the standardization of Surigaonon orthography and development of MTBMLE materials.

\section{Conclusion}

Working on the orthography in Surigaonon is considered a young project especially since people's interest in studying the language has just piqued with the implementation of MTBMLE. In this preliminary stage of community-based orthography development for Surigaonon language, several issues were identified. Though the vowel sound [a] is consistently used with the form $a$ and majority of the $[\mathrm{I}]$ sounds are widely spelled out as $i$, the $[\mathrm{u}]$ sound remains inconsistently spelled out as either $u$ or $o$. The orthographic form for the affricates also remains unpredictable as the [dz] sound is spelled out mostly using $j$ and sometimes in a variation of $d j$, $d s$, or $d z$. The similar unpredictability can also be observed in the [t $\mathrm{t}$ ] sound as it is spelled out as either ts or ch. Lastly, the use of dash is consistent for repeated sounds and for glottal stops between a consonant and a vowel. However, it becomes an issue for glottal stops between vowels as these stops are either represented by dashes or completely ignored.

With this preliminary identification of issues in Surigaonon orthography, the researcher hopes this study will inform language policymakers of Surigaonon to take into consideration how most of the speakers write the language. In addition, it is recommended that the corpus of the study be broadened in terms of democratic 
engagement by reaching out to other sectors of the community - including the farmers and fisher folks, the professionals, the children, and other members of Surigao del Norte.

\section{Acknowledgments}

The author would like to offer her warmest and most sincere gratitude to the following: Mr. Marc Ros, Prof. Iryn Cavite, Ms. Ava Villareal, and Prof. Judel Paredes of Surigao State College of Technology, and Dr. Francis Dumanig. Salamat karajaw.

\section{References}

Almario, V. (2013). Binagong gabay sa ortograpiya ng wikang Filipino. Komisyon ng Wikang Filipino. Retrieved from https://mlephil.files.wordpress.com/2013/04/binagong-ortograpiya-sa-wikangfilipino.pdf

Deliupa, S. (2012). English-Surigaonon/Surigaonon-English Vocabulary. Surigao Del Norte.

De Los Santos, N. (2015, July 21). Philippine indigenous writing systems in the modern world. Paper presented at $13^{\text {th }}$ International Conference on Austronesian Linguistics, Taipei, Taiwan.

Dumanig, F. P. (2015, March). Descriptive analysis of the Surigaonon language. Polyglossia, 27. Retrieved from http://rcube.ritsumei.ac.jp/bitstream/10367/6111/1/Francisco\%20Perlas\%20Dumanig. pdf

Dumanig, F. P. \& Jubilado, R. (2006). A descriptive analysis of Surigaonon. Paper presented at the 16th Annual Meeting of the Southeast Asian Linguistics Society, Jakarta, Indonesia.

Easton, C. (2003). Alphabetic design workshops in PNG: a community-based approach to orthography development. Retrieved from: https://www.sil.org/system/files/reapdata/26/61/00/26610043614406288022 304954448835684862/AlphabetDesignWrkshpsPNG_community_based_approac h.pdf

Fortunato, T. \& Valdez, M. S. (1995). Pulitika ng wika. Manila: De La Salle University Press. pp. 84-94.

Givertz, A. P., Lozaldo, E. B., Pedralba, R. L., Fernandez, L. S., Danaque, L. F., Manongas, J. P., Montenegro, G. P., Bonite, J. L., Ponio, A. C., Mora, S. P. \& Gases, J. G. (2013). Magbasa na kita, $1^{\text {st }}$ ed. Unpublished manuscript.

Ibon Foundation, Inc. (2004). Ibon manual on facilitating participatory research. Manila: Ibon Foundation Inc.

Komisyon ng Wikang Filipino (2016a). Ortograpiya ng Ibaloy. Manila: Komisyon ng Wikang Filipino. 
Komisyon ng Wikang Filipino (2016b). Ortograpiya ng Itawit. Manila: Komisyon ng Wikang Filipino.

Komisyon ng Wikang Filipino (2016c). Ortograpiya ng Kalanguya. Manila: Komisyon ng Wikang Filipino.

Komisyon ng Wikang Filipino (2016d). Ortograpiya ng Malaweg. Manila: Komisyon ng Wikang Filipino.

Komisyon ng Wikang Filipino (2016e). Ortograpiya ng Pangasinan. Manila: Komisyon ng Wikang Filipino.

Liwanag, M. H. C. (2015 June). A grammar sketch of Surigaonon (Unpublished master's thesis). University of the Philippines Diliman, Quezon City.

Ong, F. (2004). Surigaonon words and expressions. Las Pinas: Jose Guazon Ong.

Paredes, F. T. A. (2014). Sinurigao: pormada, plastada, tunada, pasabot. Alegria, Surigao del Norte: FTAP-SVP Publishing.

Person, K. (2001). Writing Bisu: A community-based approach to orthography development. Retrieved from SEALANG Projects: http://sealang.net/sala/archives/pdf8/person2001writing.pdf

Republic of the Philippines Department of Education (2016). Mother tongue-based learning makes lessons more interactive and easier for students [Press Release]. Retrieved from http://www.deped.gov.ph/press-releases/mother-tongue-basedlearning-makes-lessons-more-interactive-and-easier-students

Simons, G. F. \& Fennig, C. D. (2017). Ethnologue: langauges of the world (12 th edition). Dallas, Texas: SIL International. Retrieved from https://www.ethnologue.com/language/sgd

Tiukinhuy, N. O. (1981). Isang paghahambing na pagsusuri ng mga pandiwang dikaraniwan sa wikaing Surigaonon at sa wikang Filipino sa larangan ng moroplohiya ayon sa tatlong aspekto ng pandiwa (Unpublished masteral thesis). Cebu State College, Cebu City.

Victor, F. C. (2005). Lingguwistikong dibersidad: Komparatibong pagsusuri ng pagpaplanong pangwika ng India at Filipinas. In Pamela C. Constantino (Ed.), Filipino at Pagpaplanong Wika: Ikalawang Sourcebook ng Sangfil. Metro Manila: Sentro ng Wikang Filipino-UP Diliman, Sanggunian sa Filipino \& Pambansang Komisyon para sa Kultura at Sining.

Yoder, Brendon (2017, March 4). Participatory orthography development in Abawiri. Retrieved from University of Hawai'i Manoa ScholarSpace: http://scholarspace.manoa.hawaii.edu/handle/10125/42060

Zafra, G. S. (2005). Ang estandardisasyon $n g$ wika at ang pagsusulong ng Filipino sa akademya. In Pamela C. Constantino (Ed.), Filipino at Pagpaplanong Wika: 
Mariyel Hiyas Liwanag | ASEAN Journal of Community Engagement | Volume 1, Number 2, 2017

Ikalawang Sourcebook ng Sangfil. Metro Manila: Sentro ng Wikang Filipino-UP Diliman, Sanggunian sa Filipino \& Pambansang Komisyon para sa Kultura at Sining. 